\title{
Applying endosymbiosis theory: tourism and its young workers
}

\author{
Richard N.S. Robinson ${ }^{\mathrm{a}} \quad$ Tom Baum $^{\mathrm{b}} \quad$ Maria Golubovskaya $^{\mathrm{a}}$
}

David J. Solnet ${ }^{\mathrm{a}} \quad$ Victor Callan ${ }^{\mathrm{a}}$

aUniversity of Queensland $\quad$ bUniversity of Strathclyde

\begin{abstract}
Building on systems theory and its applications in tourism management, we introduce the natural science evolutionary 'endosymbiosis theory' to interpret the inter-dependencies of youth employment and tourism. Tourism organisations are located within a tourism industry or a sub-system, which in turn is bounded within a broader socio-economic ecosystem. We mobilise three classifications of symbiosis - mutualism, commensalism and parasitism to: a) test the analytic utility of this theoretical approach as a means to unpack the young worker and tourism employment relationships, and b) unify hitherto disparate literatures on the youth-tourism employment relationship. In particular, we model the explanatory value of endosymbiosis theory, navigating the ethicalities and moralities of the social sciences, in progressing our understanding of the tourism-young worker intersection.
\end{abstract}




\section{APPLYING ENDOSYMBIOSIS THEORY:}

TOURISM'S YOUNG WORKERS

\section{INTRODUCTION}

There is a mutual dependence that exists between tourism and young workers in relation to employment. Constructively, many young people find their first jobs in tourism, become active participants in the labour market, accelerate developmentally and gain useful long terms skills (Golubovskaya, Solnet \& Robinson, 2019). Concomitantly, the industry depends on, and benefits from, their youthful labour (Walmsley, 2015). Contrarily, a discourse suggests tourism and hospitality can be exploitative of young employees (cf. Bakkevig Dagsland, Mykletun \& Einarsen, 2015; Baum, 2015; Farrugia, Threadgold \& Coffey, 2018; Mooney, 2016; Smith, 2018; Walmsley, 2015). These narratives, hitherto, have not been synthesised. At the core of this paper is the view that mobilising endosymbiosis theory, and its three classifications of mutualism, commensalism and parasitism (Paracer \& Ahmadjian, 2000), provides a novel framework that allows a more comprehensive unpacking of this complex youth-tourism industry relationship, offers a more balanced perspective on tourism's relationship with its young workers and unifies disparate literatures depicting the youthtourism employment interdependency. In particular, we propose that any exploitation can be two-way, in that young workers may also exploit the conditions of tourism employment to their advantage. Directionally, this relationship can be temporally, spatially and contextually determined.

Reflecting on the discipline, Laws and Scott $(2015, \mathrm{p}$.48) posit that tourism research is beset by a "proliferation of descriptive case studies and the lack of generalisable or testable hypotheses ... [which] contrasts poorly with established disciplinary fields". In addition, tourism research is also represented by a plethora of studies that prognosticate on the complexity and diversity of its workforce (cf. Baum, Kralj, Robinson \& Solnet, 2016), but fall short of offering an explanatory means by which to address the industry's paradoxical and persistent challenges. In response, the purpose of this paper is to identify and apply theory from another discipline to explain a relationship between two phenomena in the tourism field - that of youth employment and tourism work and their mutual interdependencies. Endosymbiosis is a specific approach congruent with biological systems theory (von Bertalanffy, 1950), the utility of which has demonstrated application in the social 
sciences (von Bertalanffy, 1972), in business (Whitley, 2007), organisational studies (Hendry, 2003), employment (Allen, 2014) and tourism contexts (cf. Baggio, Scott \& Cooper, 2010; Leiper, 1979). These same principles are utilised in the employment and management literature under the label of an 'ecosystem' (Iansiti \& Levien, 2004).

Endosymbiosis theory focuses thinking upon the linkages between conceptual areas, recognising that, as Carrapico (2011, p.113) argues in the context of biological science, "we live in a symbiotic world, and one of the key characteristics of the biological systems is to establish associations and connections with other organisms". Service, or work, ecosystems mimic the characteristics of the biological world - they are dynamic, fluid and involving human and non-human actors (Subramony et al., 2018). Lusch and Vargo (2014) considered them as systems that are self-contained and self-adjusting - characterised by actors that move within and across ecosystems. Business, or work, ecosystems are a community of interacting organisations and individuals (or groups) - or the organisms of the commercial world (Baruch \& Rousseau, 2019). As others have advocated, more attention is required around the study of relationships within tourism and between tourism and its adjacent environments (cf. Merinero-Rodríguez \& Pulido-Fernandez, 2016). We follow in the footsteps of Ruddick (2003, p.334) in justifying her "attempt to create links between theories of globalization and theories of youth...". Like Ruddick (2003), this work considers young workers not as a static temporal or spatial category, but rather as a dynamic actor within broader tourism and employment ecosystems. Rather than consider all actors in the ecosystem, this paper microscopes into two key organisms, or actors - tourism (organisations) and young workers.

Predicating the utility of the natural sciences in unpacking complex interdependencies is that the biological world is characterised by social relations. In addition, the language of natural science, especially of biology, has considerable value in assisting our understanding of social science phenomena. Witzany (2005, p.51) maintains that biology should be treated as "an understanding social science", arguing that even in the natural sciences the language used to interpret positivistic evidence is socially constructed, especially in fields such as evolutionary and cell biology (cf. Kikvidze \& Callaway, 2009).

Numerous examples can be taken from the natural sciences to illustrate parallels to the core structures of youth employment. For instance, in the natural sciences there is competition for 
resources (e.g. access to the labour of youth) that predict the geographic dispersal and territoriality of organisms (e.g. labour mobility) (Maynard Smith \& Szathmáry, 1997). As another example, the organisation of populations into effective functioning groups, like herds (e.g. firms), requires a degree of discretion and influence (e.g. servant leadership) (Komdeur, 2006) or facilitative (e.g. unions) (Kikvidze \& Callaway, 2009) behaviour. Finally, there is the genetic division of labour (e.g. technical vs reproductive) such as in a beehive, and also between different life forms (Thrall, Hochberg, Burdon \& Bever, 2007) that are equally mirrored in social science contexts. Such parallels drew von Bertalanffy $(1950 ; 1972)$ to pioneer the translation of biological systems theory to the social sciences. While von Bertalanffy fully recognised the caveats in the wholesale application of his concepts to the complexities of human social systems, today general systems theory continues to have significant utility as an explanatory framework across many disciplines.

\section{YOUTH, WORK IN TOURISM AND ENDOSYMBIOSIS}

Tourism economies rely heavily on a vibrant and motivated workforce to deliver services under intense pressure to increasingly demanding customers. To meet these challenges, tourism is profoundly dependent on employees in their teens and twenties, "the youngest segments of the available labour" (Hjalager \& Andersen, 2001, p.126). Young workers, in this sense, are located within the formal tourism sector, and are part of the myriad of micro operations, often within families, that constitute informal tourism (ILO, 2010; Meyer, 2007). Indeed, the ILO (2014) highlights the importance of informal employment in most developing countries where, excluding agriculture, its scale exceeds work within the formal economy. Globally, tourism depends on young people for the execution of multiple roles in the formal and informal economies (Walmsley, 2015). Further, young workers are inimitably bound up in tourism's self- and market-image and significantly are often at the heart of its brands. This dimension of employee branding is addressed in the services marketing literature (Baker, Rapp, Meyer \& Mullins, 2014). Together, informal and formal tourism, and associated hospitality organisations, represent a large employer and act as a gateway for many young people into the workforce.

We interrogate the literature that informs this dynamic and complementary symbiosis and synthesise diverse perspectives into a framework that gives due recognition to both sides of the tourism-youth employment relationship. In particular, tourism is the conduit by which 
millions of young people enter the world of work and gain their first experiences as 'responsible' adults, whether in formal jobs or within informal or family contexts (Jennings, Breitkreuz \& James, 2013; Webbink, Smits \& de Jong, 2012). In juxtaposition to the many tropes that mark out tourism as inherently cast in the image of youth and benefiting from their exuberance, the idea that exposure to tourism employment may impact on young workers and their development is less well conceptualised. To date, there is little engagement with this aspect of the symbiotic relationship in the tourism literature (Golubovskaya et al., 2019).

\section{Youth employment and tourism jobs}

Prevailing broader political, economic and social forces have not always condoned youth employment. Cameron (2014), in his historical exposition of youth employment in Britain, shows that economic circumstances often determine the acceptability of the engagement of youth in the workforce. Fast-forwarding to the late $20^{\text {th }}$ and into the $21^{\text {st }}$ century, various policy drivers have had marked impacts on youth employment patterns, especially in developed economies. Social drivers have included the emergence of a developmental discourse which encourages workforce participation in a proscribed and managed way through schooling years as youth gain independence on the journey towards 'adulthood' (Wyn \& White, 1997). The relative prosperity shared by most developed nations has resulted in a growth of consumerism that has shaped casual employment (McDonald, Bailey, Price \& Pini, 2014). There is also the reciprocal effect of youth who are motivated to work so they can partake in this culture of consumerism (Langer, 2005). In developing countries, by contrast, demographic drivers, also labelled the 'youth bulge' (Assaad \& Levison, 2013), have increased competition for scarce jobs within the youth labour market. In turn, this has resulted in increasing dependence on the informal sector for economic survival. It is significant to note, therefore, that youth employment in tourism can be characterised by either choice or necessity - regardless, as we will establish, there is a co-dependency between the industry and young workers.

The tourism industry is one of the major employers of young people (International Youth Foundation, 2013) in countries that include Australia, Turkey, Germany and France (WTTC, 2013) and thus providing many first job experiences. Youth's current role in tourism is illustrated in an Australian context where about 50\% of high school children are in paid work at any one time and around $75 \%$ of students will work before completing school (Price, 
McDonald, Bailey \& Pini, 2011). Much of this exposure is in tourism and hospitality operations. Government statistics in Australia, for example, show that in 2016, tourism employed the highest proportion of young workers (15 to 24 years of age), with $43 \%$ working in accommodation and food services (Australian Government, 2016). Similarly, Canadian tourism is the number one employer of youth (Government of Canada, 2018) occupying 39\% of tourism jobs (UNWTO, 2009) and in the UK, nearly 30\% of hospitality employees are under 21 years of age (Fourth, 2017).

With the inexorable decline of agriculture and manufacturing as major employers, the rising significance of the service sector has provided many employment opportunities for young people. Yet, periodically the supply of youth into tourism employment varies, straining symbiosis (Divine \& Bartlett, 1988) as it responds to macro-environmental pressures (Baum et al., 2016). In terms of policy measures, deregulation across a number of areas, including minimum working age, trading hours, and changes to youth welfare arrangements, have facilitated increased opportunities for youth entry into the workforce. These developments have culminated in a broad-based increase in youth employment across developed and developing countries.

Tourism and youth employment are mutually dependent. Since tourism is the first genuine 'paid' work experience for many young people, this sector provides what is likely to be the most significant frame for their conceptualisation of work, and its cultural and social attributes. In turn, the presence of a young workforce significantly shapes workplaces and, as youth tend to engage in a high proportion of customer contact roles, they shape service delivery and the quality of tourism experiences. But this does not only apply in the context of individual businesses. Cumulatively, young employees influence the image of destinations at local, regional and national levels. Importantly, however, the voices of these young people as workers in tourism have largely been unheard, with the exception of students undertaking courses as an entry route to the industry (cf. Richardson, 2009).

The next section examines theories of symbiosis from the discipline of biology to foreground how they can be applied as explanatory lenses to explore youth employment/tourism interdependencies. 


\section{How can biology help? Endosymbiosis theory}

In biological terms, endosymbiosis refers to the dynamic evolutionary process of one organism taking up residence inside another, where at least one becomes dependent on the other for survival. Despite their apparent disparate origins, the two organisms contribute to common outcomes, even if deleterious on occasions (Martin, Garg \& Zimorski, 2015).' O’Malley (2015, p.10270) explains that "endosymbiotic relationships offer their greatest explanatory value as model systems for macroevolution. Such systems can tell us a great deal about conflict and control dynamics in ongoing organismal interactions". Indeed, these conflicts and control dynamics are as apparent in the social world as they are in the natural world.

In the natural world, organisms operate within immediate sub-systems and surrounding ecosystems, and as such, are responsive to environmental conditions and changes. In this conceptualisation, a number of dynamic ecosystems are shaped and formed in response to overarching environmental changes (e.g. socio-economic, political and cultural), such as to the labour market, education and occupational systems (cf. Baum et al., 2016). These systems interface with sub-systems. To illustrate, tourism employment is a subsystem of a broader labour market system and similarly, vocational and higher education in tourism represent subsystems within the education system. Evidently, these subsystems interface with their parent systems in accordance with the evolutionary dynamics occurring at the macro-level. , The organisms are thus located within the ecosystems and subsystems (cf. Baruch \& Rousseau, 2019). We conceptualise tourism organisations, and young workers (as a collective), as distinct organisms - as consistent with the application of ecosystems/systems theory to the business world (Hendry, 2003; Lusch \& Vargo, 2014; Subramony et al., 2018), and indeed to tourism (cf. Baggio et al., 2010; Leiper 1979).

Figure 1 depicts how the endosymbiotic process manifests. This approximates the 'input', 'process' and 'output' (I-P-O) model, axiomatic to how von Bertalanffy (1972) translated systems theory to the social sciences. I-P-O continues to traverse biology into the pure sciences (cf. Del Vecchio, Dy \& Qian, 2016) and is well-worked in the organisational

\footnotetext{
${ }^{1}$ Archibald (2015), for example, assesses the value of this theoretical framework in explaining how mitochondria and plastids, the classical membrane-bound organelles of eukaryotic cells, evolved from bacteria by endosymbiosis.
} 
literature (cf. Ilgen, Hollenbeck, Johnson \& Jundt, 2005). Here it unfolds the symbiotic relationship vis-à-vis young workers and tourism organisations.

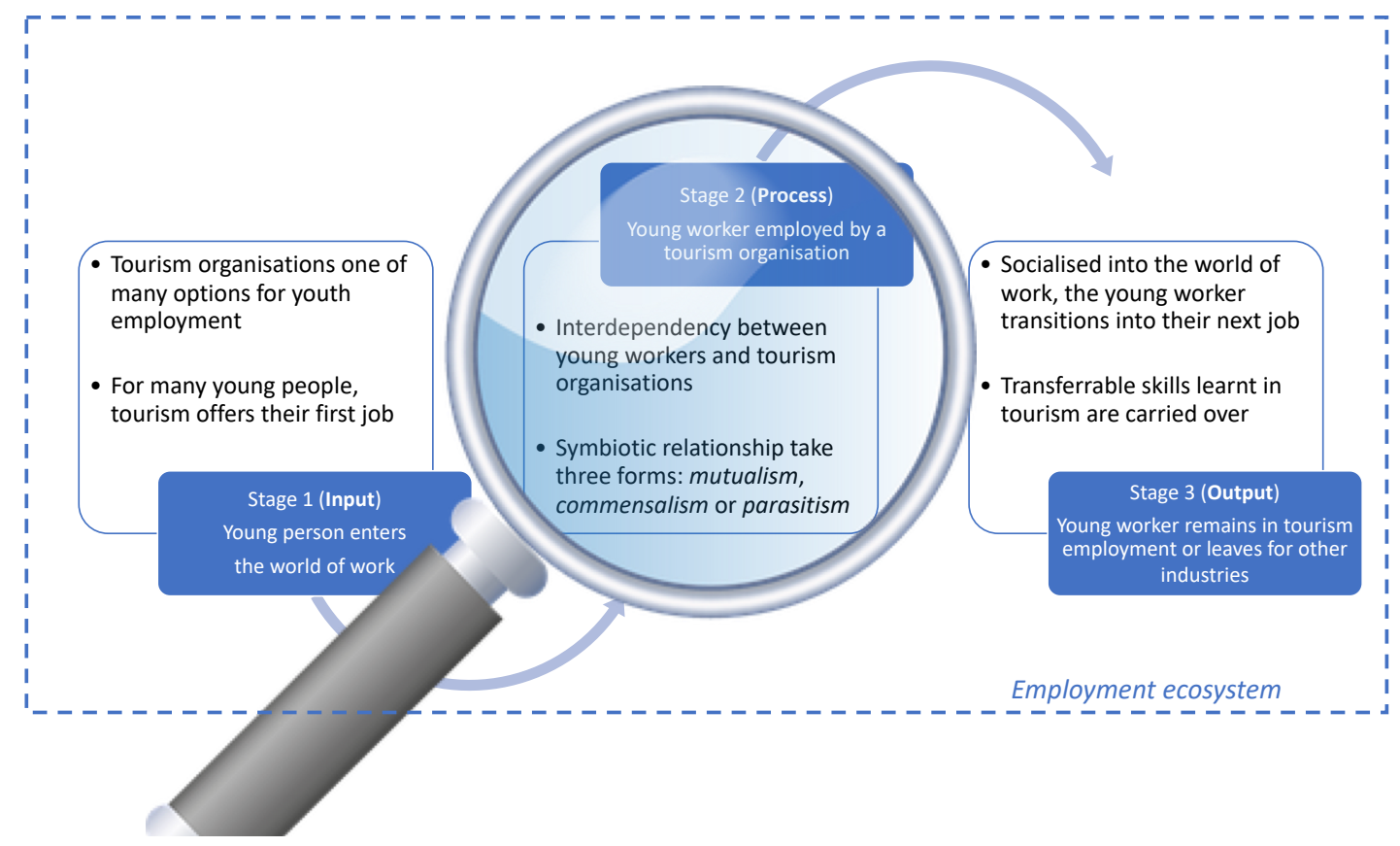

Figure 1. Endosymbiotic process between a young worker and a tourism organisation

At the 'input' (stage 1), youth experiences of tourism are largely independent, fashioned by their role as consumer or in other tangential ways, for example derived from the benefits of tourism to destinations. They exist within the same ecosystem, but operate relatively independently. Then youth enter, or 'proceed' into, the world of work, tourism organisations and young workers start sharing high levels of mutual interdependency (stage 2). On one hand, for example, youth bring many attributes to tourism and in many respects reflect its brand. On the other, since the tourism industry has traditionally been a major employer of young people, tourism jobs play a critical role in formulating first impressions of employment. These initial experiences influence 'outputs' (stage 3): future workforce citizenship values, attitudes, productivity and identity of a very significant proportion of the youth population. These consequences are critical in a) determining the quality and quantity of the tourism workforce, and b) future employment for those trained and socialised through early tourism exposure as mature workers in the labour market. Thus, subsequently, when they 'move on' into their next evolutionary stage (i.e. change jobs, careers), they transport a tourism employment 'gene', or legacy, into their next life stages similar to how genetic changes are passed onto offspring within natural sciences. This mobility of organisms 
between sub- and ecosystems is redolent of the biological world (Baruch \& Rousseau, 2019) and the I-P-O model.

In specific relation to stage 2 , the processual endosymbiotic relationship may take different forms. It is important to outline these forms in order to establish a critical baseline for a diagnosis of the youth-tourism relationship. Endosymbiosis in and of itself presumes the most desirable type of relationship between two organisms, mutualism, whereby each can coexist with stability, benefit from each other, and ultimately, even give rise to a new type of organism (O’Malley, 2015). To illustrate mutualism, the oxpecker, a bird species, feeds on ticks and other parasites that fester on rhinos or zebras. The oxpeckers get food and the beasts benefit from pest control. However, symbiosis can also take on the forms of commensalism and parasitism (Paracer \& Ahmadjian, 2000). Commensalism is a type of relationship whereby one of the organisms benefits more from the symbiosis. The cattle egret, a common heron species, is frequently observed amongst cattle herds. It devours insects concealed in ground vegetation that are disturbed by cattle. The other is neither directly helped, harmed nor damaged from the relationship. However, a parasitism is when the association benefits one organism while the other is harmed, often resulting in the morbidity of one organism. Fleas and ticks on domestic pets, find a ready food source, but irritate and infect their unwilling hosts. This is also known as antagonistic or antipathetic symbiosis. In other words, both commensalism and parasitism are one-sided symbiotic relationships.

In summary, an explanatory framework to critically analyse the contemporary relationship between young workers and tourism employment is created by identifying endosymbiosis as the process that encapsulates one of these three forms of symbiosis - as typologies of relationships. The next section applies these three forms of symbiosis to explore a number of major themes about HR, employment and tourism organisations that emerge from recent review papers of these literatures (cf. Baum et al., 2016; Kusluvan, Kusluvan, Ilhan \& Buyruk, 2010; Ladkin, 2011; Ryan, 2015; Tracey, 2014). In particular, in doing so we identify established paradoxes (Robinson, Kralj, Solnet \& Baum, 2017) and tropes (Hamilton, 2003; Putnam, Fairhurst \& Banghart, 2016) apparent in the tourism workforce literature. 
Line-level roles - cheap, flexible and available. The tourism employment system is highly dependent on labour intensity and the execution of routinised jobs that are frequently perceived to require little or no prior knowledge or skills (Baum, 2015). 'First jobbing' in tourism is primarily about front-line work, in a direct, customer-facing sense in sectors such as fast-food, cafes, restaurants and retail (Hampson \& Junor, 2005; Staff, Messersmith \& Schulenberg, 2009). Early work exposure also manifests through support roles that are 'back of house' in kitchens, store rooms or gardens. Youth are attractive for these roles because they are relatively low cost, are frequently available at peak periods of demand (e.g. weekends and school vacations), are flexible in their expectations (i.e. able to work unsocial hours) and are generally not seeking a long-term, structured relationship through their employment (in a Japanese context, for example, see Smith, 2018). On the other side of the equation, the economics of many tourism businesses, especially SMEs, seek to reduce labour costs. Employing young people provides the ideal means by which to achieve this low-cost objective (Farrugia, 2018). Flexibility, both numerical and functional (Davidson, Guilding \& Timo, 2006), and strategic ambitions, are frequently realised by the affordability of youth labour. Some of these benefits to employers may reduce in the near future as technological advancement and robotisation provide an alternative to handling the complexities and unpredictabilities of service work (Wirtz et al., 2018). By way of counter argument, Solnet et al. (2019) argue for the primacy of the human touch to enhance value creation and competitive advantage, combating the standardisation caused by ever-increasing adoptions of technology and automation.

Concomitantly, young people's transition from education to work requires exposure to the employment environment, the necessary experience that provides the key to future and better jobs. Tourism jobs have low barriers to entry, require minimum investment in terms of training in order to access them, and provide ready money. They can be abandoned at relatively low personal and professional cost, when it suits the young workers. From an employment systems perspective, the tourism industry plays an ideal, low risk, facilitating role in the transition process from education to full-time employment.

Farrugia, Threadgold and Coffey (2018) extend this argument to explain how the nature of work on offer, in turn, impacts on young workers in exploring the complexity that arises from the interface of front of house work and youth's search for identity. Endosymbiosis' 
evolutionary and dynamic properties, alluded to by O'Malley (2015), exist in the sense that, with adolescence being a time of conflict in a search for a personal identity, tourism employment offers the context for the playing out of this search for a personal identity. This use of the tourism employment context for 'playing out' identities can come at the costs of productivity, congenial workplace relations or adherence to service standards (Solnet, Kralj \& Kandampully, 2012), thus bearing out something of an uneven relationship whereby young workers could benefit more fully than organisations. The hallmarks of this relationship (providing a partial map to stage 2 in Figure 1) though is largely mutually beneficial. Youth employment constitutes low-cost labour for employers, while tourism affords the benefits of a relatively easy gateway into the 'world of work' for youth.

Temporal/flexible/precarious work - where I want it, when I want it, leave it on my terms. Tourism is an industry with considerable diversity in the skills and attributes required in its various jobs. There is a high level of contingency dependence linked to location, business focus, size, ownership, quality level, target markets, seasonal influences and local labour markets. Labour demand largely coincides with the availability of potential young employees within the local community - evenings, weekends and school vacations (Joliffe \& Farnsworth, 2003). The geographical dispersal of tourism enterprises within every town and community means that they rely on effective and localised recruitment of potential young employees. In mutualistic terms, this provides diverse opportunities. In the view of Smith (2018, p.89), the precariousness of tourism employment has enabled youth to come to terms with, and make sense of, an emergent post-industrial or neoliberal order "even as they are exploited and shaped by it".

Furthermore, there is short-termism in the financial planning for small businesses in the sector (Tsai, Pan \& Lee, 2011). The ability to invest in sustainable human resource practices (Ehnert, Harry \& Zink, 2014) such as planned staff retention strategies, training and development, can be limited or absent. These factors combine to make young workers, often without experience, desirable employment targets. Often driven by a need to gain experience and build resumes, youth are more likely to accept precarious working conditions: that is, casualised, on-call, part-time, even unpaid trials or ongoing under-payment. 
Arguably, a more attractive aspect of tourism jobs for youth includes the perceived social value of interactive service work in tourism, allowing young workers to build positive personal networks (Ellingson, Tews \& Dachner, 2016). Besides, most of this tourism, and more specifically hospitality, work 'is there' (Baum, 2006), accessible in the neighbourhoods where young people live or study. Tourism is a ubiquitous industry like few others (retail and agriculture have similarities) and young people are there and ready to work in the sector - an endosymbiotic process borne of a relationship of mutual convenience.

Mobility - functional, organisational, geographical. Linked to the above, tourism employment offers lifestyle opportunities in sun, sand, sea and snow destinations (Thulemark, Lundmark \& Heldt-Cassel, 2014) - often desirable for young people. Variable demand, especially seasonality, while reducing the security and permanence of employment in many areas (Ainsworth \& Purss, 2009; McCole, 2015), also accords with the availability of young people on weekends and during school/ college breaks. There is evidence that youth actively choose tourism employment when taking extended travel breaks; for instance, 'gapyears' or when backpacking (Harmer \& Rogerson, 2017). This manifests as an interesting case of youth choosing to work in an industry and in destinations that themselves cater to youth, such as backpacker hostels, bar work and 'hired hands' on adventure tourism products like bungee jumping and white-water rafting (Giddy, 2019 forthcoming). The intersection of lifestyles and mobility - inherent to both young workers and tourism - is apparent in this endosymbiotic process, which is characteristic of commensalism.

Notably, the recognition of this form of work for youth is neglected, for instance by Richards (2015) in a comprehensive review of contemporary youth nomadism. Indeed, youth lifestyle employment in these situations not only affords destinations with a ready-and-willing workforce, but also a market as young workers become customers off-shift. As Cohen, Duncan and Thulemark (2015) and others (e.g. Cohen, 2011) have noted, there is a blurring of youth identities of inter alia traveller, student, holiday-maker, temporary resident and employee. This ability of young workers to transition across work and leisure boundaries challenges the notion that youth are exploited by tourism employment as there is youth agency in these lifestyle contexts. In other words, young people choosing to work in tourism, as a deliberate and mostly temporary lifestyle choice (cf. Duncan, Scott \& Baum, 2013) is suggestive of complicit and informed employment choices. 
Multiple competencies and skills. There is no scarcity of literature discussing the characteristics of tourism jobs. The working opportunities that tourism offers are located across the abilities and aspirational range (Baum, 2006). The sector has the capacity to accommodate those with high level career and skills ambitions, alongside a low skilled and lower paid temporary and transitory cohort. For example, there is evidence that some hospitality organisations create employment for those with relatively severe disabilities (Kalargyrou \& Volis, 2014). Paez and Arendt (2014, p. 187) found that hotel and restaurant managers "had a somewhat positive attitude toward training and working with people with disabilities", though severity of disability is the strongest predictor of employment (Bush \& Tassé, 2017). However, caution should be exercised here as others have suggested the wholesale inclusion of marginal groups could be considered the exception rather than the rule (Carter, Austin \& Trainor, 2012). Nonetheless, deskilling in some sub-sectors, especially food production and service, allows more general access to positions previously protected by specific skills requirements (Knox, 2016; Robinson \& Barron, 2007).

The acquisition of soft skills may contribute to the flexibility that is much-prized by employers, alongside positive worker attitudes and the ability to apply skills in various workplace contexts (Bolton \& Houlihan, 2007). These generic skills have much wider transferability to other sectors of the economy (see stage 3 in Figure 1), and provide the basis for work across many employment environments, particularly in the service sector (Richardson \& Butler, 2012). This transferability of learning may provide a partial explanation for the historically high attrition of early career university and college students graduating from tourism programs (Pavesic and Brymer, 1989). Studies have noted attrition of a third of tourism graduates in various countries (e.g. in the US - Brown, Arendt \& Bosselman, 2014; in Portugal - Costa, Breda, Malek \& Durão, 2013; in China - Lu \& Adler, 2008), although in some studies this number reaches over $40 \%$ (Richardson, 2008). These graduates could take the skills acquired in these programs, tourism work, and work integrated learning experiences, and use them to gain employment in other industries. These benefits that tourism provides to young workers recalibrate the acceptability of employment in the sector and further illustrates endosymbiotic mutuality. However, endosymbiosis does not always yield such seemingly equally-weighted and reciprocal relationships. 
Looking the brand. Many tourism jobs require a level of deliberate presentation, which Goffman's (1949) celebrated performativity metaphor is often used to explain. A clear commensal symbiosis is evidenced when considering the aesthetics of tourism labour. Employer preferences reflect aesthetic priorities by an industry focusing on employees who look and sound 'good' (Warhurst \& Nickson, 2007), even by those that might perform less visible roles. Housekeepers perform not just for guests but often to cross-departmental colleagues and managers, as they negotiate their own dignity and sense of doing a worthwhile job (Kensbock, Jennings, Bailey \& Patiar, 2016). Similarly, customers often favour the vibrancy and vitality that young workers inherently bring to service encounters. Farrugia $(2018$, p.512) refers to "the concept of youthfulness as a quality that circulates in the new economy to attribute a particular kind of value to immaterial products and to labouring subjectivities themselves".

Generally, younger workers are more likely to meet the industry's aesthetic criteria than their older colleagues. Youthful appearances, or older persons pressured to embrace youthful looks, are prolific in customer-facing contexts. Indeed, McDowell (2009) emphasises the critical role of the youthful-looking body, or 'body work', as an important attribute for employment of young workers in the service industries, especially in Western contexts. This imposes certain 'body' performance standards to fit the conditions of labour (Winker \& Degele, 2011). These performance standards are exacerbated in the aestheticisation of gender (cf. Simpson, 2004), marginalisation of body types in tourism labour (cf. Harris \& Small, 2013 regarding obesity and hotel work), ableism (McIntosh \& Harris, 2018) and in more complex intersectionalities (Gruys, 2012; MacDonald \& Merrill, 2009; Rodó-de-Zárate, 2017).

Despite these critical perspectives on aesthetic labour and its performance, youthful looks, and how they intersect with various gendered, aged, abled, ethnic and religious identities, are desired by employers (Mooney, 2016). Young workers are more likely to conform to expectations with respect to employee branding in tourism, identifying in both aesthetic and cultural terms with the services they deliver (Besen-Cassino, 2014). This creates distinct advantages for youth, and youth employment, and depicts a communalistic relationship between young workers and tourism organisations. 
However, tourism's dependency on young workers' looks may also backfire, and even lead to a parasitic relationship. When young people are unable to conform to a brand, for cultural, emotional or aesthetic reasons, they are excluded and marginalised. As Genz (2015) argues, gendered branding leads to a coalescence of the individual, her appearance, self-image and her job ('my job is me') in the eyes of contemporary youth. Working in roles that present less than positive imagery by the nature of the job, the uniform and performance expectations can have a negative impact on the self and self-esteem. Therefore, embracing an intersectional perspective, tourism risks being culturally and socially exclusionary. Tourism might deny those from marginalised communities access to, and opportunities for, work that reflects their aspired 'brand' status (Tinson, Piacentini, Nuttall \& Cocker, 2017). Applying endosymbiosis, a process of 'natural selection' is apparent here - the host tourism organism innately selects the specific characteristics of the commensal guest - young worker.

Nonetheless, it is evident that the industry and destinations leverage organisational and occupational branding by harnessing various youth attributes. These traits promote the industry as vital, fun, and even hedonistic. They capture a sense of youthful abandonment which is key to driving the experience economy in which tourism trades (Chang, 2018; Gilmore \& Pine II, 2002). As Wallace, Lings, Cameron and Sheldon (2014) highlight, recognising brand attributes - of certain forms of employment, industries and employers can become an invaluable recruitment and retention tool.

Employer branding (Foster, Punjaisri \& Cheng, 2010) represents the conscious leveraging of a product or service brand as a means to attract and retain the best talent. Employee branding, which is commonplace in tourism, makes direct use of workers in order to reinforce brand attributes (e.g. youth, fun) in the eyes of the market (Harquail, 2004). This leads to the notion of 'living the brand' along the lines of the theme park expectations of their team (cf. Baker et al., 2014), whereby employees become the embodiment of the brand in a real sense. The host organism becomes imbued with the characteristics of youth, which enhances its competitiveness and its survival in biological terms. While young workers are not necessarily harmed in the various manifestations of the way their youthfulness is harnessed for organisational and industry aggrandisement, the relationship between these two elements in the broader ecosystem is symbiotic. 
Youthful energy and being 'cheap'. As noted, young employees bring a unique and valued dynamic into the tourism workplace (Mooney, 2016). At least, the industry's rhetoric suggests that a sense of its value as a descriptor of tourism as a 'young people's industry' is widespread. Farrugia et al. (2018, p.272) highlight how young people doing bar work "contribute to the production of affective atmospheres, or sensations of ease, pleasure and enjoyment that are offered to clientele of boutique bars".

Such outcomes are evident through a number of lenses. Some scholars have referred to discriminatory practices by tourism employers against older workers ('ageism') by which younger workers are favoured at times of recruitment, promotion and retrenchment (Magd, 2003; Martin \& Gardiner, 2007). Concomitantly, Zhong and Hertzman (2014) report ambivalent feelings among young people when they work with older colleagues relating to the benefits and limitations of such arrangements. For example, Asian-heritage young people may find it difficult to work with older employees as they may be in a constant state of culturally-conditioned respect that inhibits their ability to naturally perform the same tasks on equal terms with their older colleagues. This rhetoric suggests that tourism capitalises on youths' look and image, often at a cost to other employees, as for example, with the ageism inherent to Zhong and Hertzman's (2014) findings. Nonetheless, while young workers might benefit from the aesthetic qualities in their initial selection and recruitment by tourism and hospitality organisations, other research (e.g. Lucas \& Keegan, 2007) suggests that regardless of skill levels over the medium-term youth are penalised by lower pay than older workers.

Young people's perceived capacity is to work hard, effectively and flexibly compared to other age groups, including working antisocial hours. They do so as long as the paths to achieving long-term career and life benefits within or external to the industry are visible (Barron, Leask \& Fyall, 2014; Lub, Bijvank, Bal, Blomme \& Schalk, 2012). However, there is evidence that young people are actually rejecting tourism and hospitality employment. For example, evidence from New Zealand (Williamson, 2017) suggests that despite huge demand for line-level roles, youth do not perceive the value of employment in the sector. In addition, evidence from Scandinavia (Bakkevig Dagsland et al., 2015) points to youth rejecting training pathways to employment in the industry. 
There is also strong evidence around labour exploitation of young workers. Baum (2015) draws a disconcerting picture of wasteful and irresponsible HR practices which often dominate tourism employment. Similarly, Solnet, Kralj and Baum (2015) found that the HR function within hospitality businesses is devolving, with increasing foundational HR responsibilities shifting towards line managers, supervisors and often young workers themselves. This is consistent with calls for more responsible employment practices in tourism and hospitality (Baum \& Mooney, 2019), whereby organisations should look beyond job creation in order to provide contexts for the positive development of youth. This evidence suggests that the association between young workers and tourism, with one living at the cost of the other, is a form of parasitism. Should the balance of benefits swing too far in tourism's favour, and youth see other labour market opportunities for example in retail or the online gig economy, the positive aspects of endosymbiosis may come under threat.

Youth vulnerability to exploitation and abuse. The critical mobilisation of parasitism is nowhere more challenged than in the various ways young people are cynically exploited in tourism work. Tourism employment can take on a distinctly dark side and is clearly exploitative of young people and, indeed, of those who are classified as children. Child labour, slavery (Robinson, 2013) in tourism, is a universal phenomenon and exists in differing forms and with varying intensity in all countries (Hagedoorn, 2013), though predominantly the developing world. Child work in tourism is widely illustrated in the literature, but empirical data on its prevalence and characteristics are sketchy (Black, 1995; Edralin, 2002). For example, in developing economies indentured labour exists in clearly exploitative relationships (Robinson, 2013). Alternatively, strong industrial relations in developed economies give some protection from full exploitation, although there is still evidence of frequent sexual harassment (Poulston, 2008) and bullying (Robinson, 2008). Clearly, conditions in the developed and developing world 'ecosystems' drive differing, though sometimes intersecting, interdependencies between young workers and tourism employment.

The reputation of tourism as a low skills and undesirable workplace has some self-fulfilling consequences. In the United States, for example, $38 \%$ of employers in tourism express concern at the poor skill levels of new employees, compared with $25 \%$ in other sectors of the economy (International Youth Foundation, 2013). Despite recent attempts to redress negative 
perceptions of tourism industry jobs, the dominant discourse regarding perceptions of many forms of its youth employment is framed as an exploitative one. While this perspective is often driven by polemic (e.g. Ritzer, 1993; Schlosser, 2002) rather than empirical work, there is evidence of an absence of training and development for both interns and new young employees (cf. Ineson, Jung, Hains \& Kim, 2003; Poulston, 2009) that leads to reduced lower self-efficacy and poorer job satisfaction. Thus, while our discussion characterises some of the ways in which young workers are mobilised in tourism employment as exploitative, or parasitic, if one party or another is prepared to bear the costs of a relationship, this relationship more closely approximates commensalism (Paracer \& Ahmadjian, 2000).

In this dissection of symbiotic relationships between tourism and young workers, framed within the process stage of the I-P-O model, the dominant discourse is one with tourism as the primary parasite. However, it is naive to suggest that youth are always the victim. The low switching costs of young people, given that their employment is often a matter of choice for discretionary income rather than a need, contributes to high rates of turnover significantly impacting upon organisational profitability (Guilding, Lamminmaki \& McManus, 2014). Youth have higher rates of absenteeism than other cohorts, for example older workers (Jenkins, 2018), and they are perceived to be less productive (Green, Sissons, Qamar \& Broughton, 2018). Two critical points emerge. First, the direction of mutuality, whether commensal or parasitic, is not necessarily pre-determined or constant just as it is not in the natural world. Second, pure biological representations of endosymbiosis (see Figure 1) lead us to presuppose that one organism in the ecosystem 'consumes' the other element, thus determining the nature of the symbiosis. Our critical analysis, however, shows that in the broader social, economic, political and cultural context, this is not so. Nonetheless, degrees of exploitation are certainly evident, analogous to parasitism.

\section{CONCLUSIONS}

This paper invoking the application of endosymbiosis theory was motivated by evidence of the explanatory utility of previous applications of biological systems thinking (von Bertalanffy, 1950; 1972) to organisations (Hendry, 2003; Ilgen et al., 2005; Whitley, 2007) and tourism (cf. Baggio et al., 2010; Leiper, 1979). We illustrate that the relationship between young workers and tourism organisations is dynamic and processual, as consistent with the evolutionary nature of endosymbiosis as relating to two organisms (O’Malley, 2015), and framed within the process stage of the I-P-O model (Del Vecchio et al., 2016). Likewise, 
relations in the natural sciences are social, and can be based on discretionary behaviours (Kikvidze \& Callaway, 2009). As our critique has established, these relationships can be of mutual advantage, but also exploitative. This reality is not dissimilar to many relationships in the natural world (Paracer \& Ahmadjian, 2000). In addition, we have recognised examples, consistent with the natural sciences, of the three forms of symbiosis: parasitism, commensalism and mutualism.

One of the difficulties of translating the natural sciences into the social sciences is that the natural world is devoid of the ethical and moral imperatives that characterise the Anthropocene. To accommodate appropriately the ethical and moral nuances of the human experience, any translation of endosymbiosis theory to the social sciences must embrace a progression from exploitative relations to, at the very least, more balanced commensalism, and ideally to harmonised and mutual forms of the endosymbiotic process. We model this evolutionary endosymbiotic process, integrating the moral imperative in Figure 2, illustrating how an evolutionary directionality towards ethical and moral mutualistic benefits is embraced. Moreover, this preliminary model also synthesises disparate literatures or perspectives vis-à-vis the youth-tourism employment phenomena by mobilising three types of interdependencies, as the interpretative device.

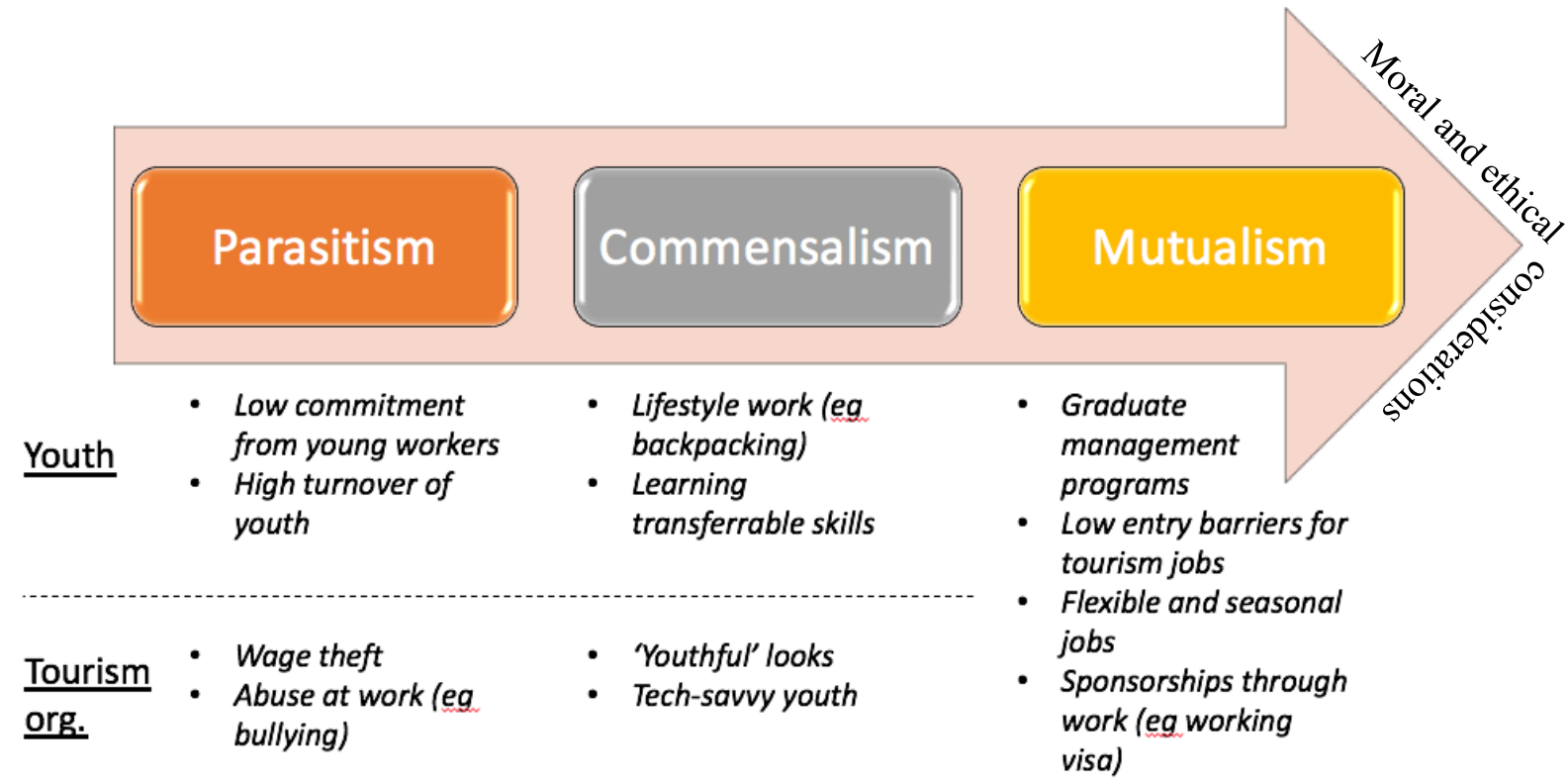

Figure 2. Translation of an endosymbiotic evolutionary continuum into the social sciences 
As Figure 2 proposes, various manifestations of the youth-tourism employment relationship can be plotted on the directional continuum, underpinned by uniquely human ethical and moral principles. Figure 2 provides specific illustrative examples of parasitic behaviours from the perspective of young workers (e.g. low commitment) and of organisations (e.g. wage theft); of commensalism, again from both perspectives (e.g. lifestyle workers benefitting from but not harming organisations or organisations benefitting from tech-savvy youth, but not harming them per se); progressing to mutualism, where such binaries are less apparent, if not irrelevant. Regardless, young workers and tourism are enmeshed in a symbiotic relationship. Youth gain 'first job' entry paths into the labour market, while tourism organisations access affordable and flexible workers.

Despite the moral imperative, this paper does not 'moralise'. Not all parasitic relationships should be stigmatised - for example, disengaged young people in front line roles (e.g. Lub et al., 2012). Similarly, commensal relationships are suggestive of conscious sacrifices. Like all relationships, there is an element of balancing sacrifice for benefit (cf. the job embeddedness HR theory; Robinson, Kralj, Solnet, Goh \& Callan, 2014). Still, similar to the wider social sciences, this model cannot as yet fully accommodate a range of inherent paradoxes (Putnam et al., 2016), including those recently highlighted in tourism employment (Robinson, Ritchie et al., 2014). These paradoxes can occur between developed and developing economies, as observed, within sectors, for example hotel employment conditions, or SMEs operating in the formal or grey economies, or even between departments in one organisation. For example, nefarious parasitic practices in commercial kitchens (Bakkevig Dagsland et al., 2015), and housekeeping (Kensbock et al., 2016), might co-exist with mutualistic ones in the accounting or finance departments.

This theoretically-informed preliminary framework has several implications, for example, in conceptualisations of neglected tourism employment relations (Baum, 2015; Baum et al., 2016), for the development of tourism theory around the roles of symbiotic and systemsbased phenomena and relationships, and in tourism and hospitality practice. As an explanatory tool endosymbiosis has the potential to assist in the understanding of other interlocking and dependent tourism relationships. There is clearly a need for wider conceptualisation of the nature of these relationships and empirical research. In line with calls by Laws and Scott (2015), there is the need to explore the levels and depth of dependency, making use of both quantitative and qualitative methodological approaches. For instance, 
tourism is promoted as an increasingly important economic opportunity at the community level in many countries. In what ways do the requirements of key elements within the tourism system at a local level interact with the wider socio-economic and cultural needs of that community? At the same time, tourism can challenge the sustainability of such attractions and compromise their authenticity. The framework of endosymbiosis can add understanding to the relationships that exist between tourism and these environments.

In addition, there are risks that need to be investigated. What if the ongoing balance of mutuality to both 'organisms' was de-coupled, highlighting negative outcomes to individuals, social institutions (e.g. schools), organisations, occupations, destinations and entire economies? Perhaps career theories (e.g. Super, 1980 \& Protean careers) could frame, longitudinally, how workers, who intersect with tourism in their youth, fare over the long haul? In addition, there are opportunities to telescope out to interrelationships between other actors in the broader ecosystem. For example, the role educators play at stage 1 (input) or, within the process (stage 2), to what degree competing interests of stakeholders (e.g. peak bodies, policy makers, unions) determine whether young workers and organisations experience mutualism, commensalism or parasitism? Some of the unpalatable contingencies that we have navigated, tinged with the moralities and ethicalities that the translational natural sciences cannot suitably treat, highlight the need for a concerted research agenda. Research to explore these systems and relationships through a convergence of endosymbiosis and systems theories provides a challenging future agenda.

\section{Some final caveats}

In this critical discussion, guided by the endosymbiotic process (O'Malley, 2015) we examined various discourses of intersection, between young workers and tourism. However, there are underpinning and complex contingencies within these discourses that we wish to reaffirm. We are conscious of the definitional challenges that tourism presents, the diversity of tourism organisations and systems, and the consequences of such issues for employment within both formal and informal sectors. Also, we acknowledge the contingent ways in which tourism relates to the wider economic, political, social, cultural and technological landscape in which it is located, not least the contrast between developed and less-developed countries as the hallmark of critical social sciences. 
The world of molecular and evolutionary biology and the world of tourism, employment and young workers, are not completely parallel environments. Although von Bertalanffy's pioneering work $(1950 ; 1972)$ of applying biological systems theory to social science systems sets a well-accepted precedent that we follow there are issues in the translation of the natural sciences to the social world. We have provided a critical discussion of how the natural world is social and relational (cf. Kikvidze \& Callaway, 2009), and how discretionary, rather than absolute, behaviours govern the natural world as commensurate with the world of humans. This position counters views that the natural sciences are governed by various deterministic laws, for example, the Darwinian theory of the 'survival of the fittest'. Therefore, we cannot entirely frame the tourism youth employment nexus without due consideration for the ecosystem within which they exist. In addition, a unique capacity of the human is to consider more abstract notions of ethics and morality. Clearly, there is not any translation of these ideologies from natural science to social science. If one overlays these moral frameworks, it is logical that commensalism at the very least, and mutualism, are highly desirable, and that parasitism is unconscionable. This distinction becomes the fulcrum of our major conclusions, as modelled in Figure 2.

Finally, we acknowledge that the bulk of the extant literature draws on developed countries, or destination-based views, of tourism and of youth employment. For example, in the developed world context there is the normative view that adolescents transitioning from childhood are characterised by a move from dependency to a search for independence (cf. Roberts, 2007). In the process of developing independence, the normative view posits, they need to be socialised into the world of work, so diminishing the role of youth agency rather emphasising the structural factors at play. Similarly, there are risks linked to neo-liberal assumptions about the nature of work, the economy and society. As Bianchi (2009) argues the dominant neo-liberal paradigm driving tourism policy and employment practices glosses over inequalities in the tourism workplace. The degree to which young workers and tourism organisations are subject to these meta-assumptions is doubtless wide and varied. There are clear dangers of treating youth as a homogenous organism, or for treating those living and working in the developed versus developing worlds as one. 


\section{REFERENCES}

Ainsworth, S. \& Purss, A. (2009). Same time, next year? Human resource management and seasonal workers, Personnel Review, 38(3), 217-235.

Allen, M.M.C. (2014). Business systems theory and employment relations. In A. Wilkinson, G. Wood \& R. Deeg (Eds.), The Oxford Handbook of Employment Relations (pp.86113), Oxford: Oxford University Press.

Archibald, J. (2015). Endosymbiosis and eukaryotic cell evolution. Trends in Biochemical Sciences, 25(19), R911-R921.

Assaad, R. \& Levison, D. (2013). Employment for youth: A growing challenge for the global community. Minnesota Population Centre (MPC), Working Paper 2013-07, Minneapolis, MN: MPC.

Australian Government. (2016). Australian jobs 2016. Department of Employment. Retrieved from https://www.employment.gov.au/australian-jobs-publication.

Baggio, R., Scott, N. \& Cooper, C. (2010). Network science: A review focused on tourism. Annals of Tourism Research, 37(3), 802-827.

Baker, T., Rapp, A., Meyer, T. \& Mullins, R. (2014). The role of brand communications on front line service employee beliefs, behaviors, and performance. Journal of the Academy of Marketing Science, 42(6), 642-657.

Bakkevig Dagsland, Å.H., Mykletun, R.J. \& Einarsen, S. (2015). “We're not slaves-we are actually the future!" A follow-up study of apprentices' experiences in the Norwegian hospitality industry. Journal of Vocational Education \& Training, 67(4), 460-481.

Barron, P., Leask, A. \& Fyall, A. (2014). Engaging the multi-generational workforce in tourism and hospitality. Tourism Review, 69(4), 245-263.

Baruch, Y. \& Rousseau, D. M. (2019). Integrating psychological contracts and ecosystems in career studies and management. Academy of Management Annals, 13(1), 84-111.

Baum, T. (2006). Human resource management for tourism, hospitality and leisure: An international perspective. London: International Thomson. 
Baum, T. (2015). Human resources in tourism: Still waiting for change? - a 2015 reprise. Tourism Management, 50, 204-212.

Baum, T., Kralj, A., Robinson, R.N.S. \& Solnet, D.J. (2016). Tourism workforce research: A review, taxonomy and agenda. Annals of Tourism Research, 60, 1-22.

Baum, T. \& Mooney, S. (2019) Hospitality employment 2033: A backcasting perspective, International Journal of Hospitality Management, 76(B), 45-52.

Besen-Cassino, Y. (2014). Consuming work. Youth labor in America. Philadelphia: Temple University Press.

Bianchi, R.V. (2009). The 'critical turn' in tourism studies: A radical critique. Tourism Geographies, 11(4), 484-504.

Black, M. (1995). In the twilight zone: Child workers in the hotel, tourism and catering industry, Geneva: ILO.

Bolton, S. \& Houlihan, M. (2007). Beginning the search for the H in HRM. In S. Bolton \& M. Houlihan (Eds.), Searching for the human in human resource management: Theory, practice and workplace contexts (pp. 1-28), Basingstoke: Palgrave.

Brown, E. A., Arendt, S. W. \& Bosselman, R. H. (2014). Hospitality management graduates' perceptions of career factor importance and career factor experience. International Journal of Hospitality Management, 37, 58- 67.

Bush, K.L. \& Tassé, M.J. (2017). Employment and choice-making for adults with intellectual disability, autism, and down syndrome. Research in Developmental Disabilities, 65, 2334.

Cameron, S. (2014). Earning, learning and income. Unpublished Doctoral dissertation, University of Central Lancashire.

Carrapico, F. (2011). The symbiotic phenomenon in the evolutive context. In O. Pombo, J-M. Torres, J. Symons \& S. Rahman (Eds.), Special sciences and the Unity of Science (pp. 113-119), Berlin: Springer.

Carter, E., Austin, D. \& Trainor, A. (2012). Predictors of post-school employment outcomes for young adults with severe disabilities. Journal of Disability Policy Studies, 23(1), 5063.

Chang, S. (2018). Experience economy in hospitality and tourism: Gain and loss values for 
service and experience. Tourism Management, 64, 55-63.

Cohen, S.A. (2011). Lifestyle travellers: Backpacking as a way of life. Annals of Tourism Research, 38(4), 1535-1555.

Cohen, S.A., Duncan, T. \& Thulemark, M. (2015). Lifestyle mobilities: The crossroads of travel, leisure and migration. Mobilities, 10(1), 155-172.

Costa, C., Breda, Z., Malek, A. \& Durão, M. (2013). Employment situation of tourism graduates working in and outside the tourism sector. GSTF Business Review (GBR), 3(1), 141-146.

Davidson, M., Guilding, C. \& Timo, N. (2006). Employment, flexibility and labour market practices of domestic and MNC chain luxury hotels in Australia: Where has accountability gone? International Journal of Hospitality Management, 25(2), 193-210.

Del Vecchio, D., Dy, A.J. \& Qian, Y. (2016). Control theory meets synthetic biology. Journal of The Royal Society Interface, 13(120), 1-17.

Divine, H.A. \& Bartlett, A.L. (1988). Teenage employment in hospitality: Attitudes, outcomes and analysis. Journal of Hospitality \& Tourism Research, 12(2), 431-441.

Duncan, T., Scott, D.G. \& Baum, T. (2013). The mobilities of hospitality work: An exploration of issues and debates. Annals of Tourism Research, 41, 1-19.

Edralin, D. (2002). Child labor in the tourism industry. Notes on Business Education, 5(2), 16.

Ehnert, I., Harry, W. \& Zink, K. (2014). Sustainability and HRM. In I. Ehnert, W. Harry \& K. Zink (Eds.), Sustainability and human resource management: Developing sustainable business organizations (pp.3-34), Dordrecht: Springer.

Ellingson, J.E., Tews, M.J. \& Dachner, A.M. (2016). Constituent attachment and voluntary turnover in low-wage/low-skill service work. Journal of Applied Psychology, 101(1), 129-140.

Farrugia, D. (2018). Youthfulness and immaterial labour in the new economy. Sociological Review, 66(3), 511-526.

Farrugia, D., Threadgold, S. \& Coffey, J. (2018). Young subjectivities and affective labour in the service economy. Journal of Youth Studies, 21(3), 272-287. 
Foster, C., Punjaisri, K. \& Cheng, R. (2010). Exploring the relationship between corporate, internal and employer branding. Journal of Product \& Brand Management, 19(6), 401409.

Fourth (2017). Hospitality workforce statistics: The people powering the industry. Retrieved from https://www.fourth.com/en-gb/blog/hospitality-workforce-statistics

Genz, S. (2015). My job is me. Postfeminist celebrity culture and the gendering of authenticity. Feminist Media Studies, 15(4), 545-561.

Giddy, J. (2019 forthcoming). Insight into adventure tourism employment in South Africa. In T. Baum \& A. Ndiuini (Eds.), Sustainable Human Resource Management in Tourism. African Perspectives, Berlin: Springer.

Gilmore, H.J. \& Pine II, B.J. (2002). Differentiating hospitality operations via experiences: Why selling services is not enough. Cornell Hotel \& Restaurant Administration Quarterly, 43(3), 87-96.

Goffman, E. (1949). Presentation of self in everyday life. American Journal of Sociology, 55, 6-7.

Golubovskaya, M., Solnet, D. \& Robinson, R.N.S. (2019, in press). Recalibrating talent management for hospitality: A youth development perspective. International Journal of Contemporary Hospitality Management.

Government of Canada (2018). Canada's tourism vision: One year of progress. Innovation, science and economic development Canada. Retrieved from https://www.ic.gc.ca/eic/site/095.nsf/eng/00007.html

Green, A., Sissons, P., Qamar, A., \& Broughton, K. (2018). Raising productivity in low-wage sectors and reducing poverty. Accessed at https://www.jrf.org.uk/reports

Gruys, K. (2012). Does this make me look fat? Aesthetic labor and fat talk as emotional labor in a women's plus-size clothing store. Social Problems, 59, 481-500.

Guilding, C., Lamminmaki, D. \& McManus, L. (2014). Staff turnover costs: In search of accountability. International Journal of Hospitality Management, 36, 231-243.

Hagedoorn, E. (2013). Child labour and tourism. How travel companies can reduce child labour in tourism destinations, ICRT Occasional Paper N. 26, Leeds: The International Centre for Responsible Tourism. 
Hamilton, P. (2003). The saliency of synecdoche: The part and the whole of employment relations. Journal of Management Studies, 40(7), 1569-1585.

Hampson, I. \& Junor, A. (2005). Invisible work, invisible skills: interactive customer service as articulation work. New Technology, Work and Employment, 20(2), 166-181.

Harmer, D. \& Rogerson, J. (2017). Gap year tourism: International debates, South African issues. African Journal of Hospitality, Tourism and Leisure, 6 (1), 1-11.

Harquail, C. (2004). Employees as animate artifacts: Employee branding by "Wearing the Brand”. In A. Rafaeli \& M. Pratt (Eds.), Artifacts and Organizations. Beyond mere symbolism (pp. 161-180), Mahwah, NJ: Lawrence Erlbaum.

Harris, C. \& Small, J. (2013). Obesity and hotel staffing: Are hotels guilty of 'lookism'? Hospitality \& Society, 3(2), pp.111-127.

Hendry, C. (2003). Applying employment systems theory to the analysis of national models of HRM. The International Journal of Human Resource Management, 14(8), 1430-1442.

Hjalager, A.M. \& Andersen, S. (2001). Tourism employment: Contingent work or professional career? Employee Relations, 23(2), 115-129.

Iansiti, M. \& Levien, R. (2004). Strategy as ecology. Harvard Business Review, 82(3), 68-81.

Ilgen, D.R., Hollenbeck, J.R., Johnson, M. \& Jundt, D. (2005). Teams in organizations: From input-process-output models to IMOI models. Annual Review of Psychology, 56, 517543.

ILO [International Labour Office] (2010). Decent work and the informal economy. Geneva: ILO.

ILO [International Labour Office] (2014). Transitioning from the informal to the formal economy. Geneva: ILO.

Ineson, E.M., Jung, T., Hains, C. \& Kim, M. (2013). The influence of prior subject knowledge, prior ability and work experience on self-efficacy. Journal of Hospitality, Leisure, Sport \& Tourism Education, 12(1), 59-69.

International Youth Foundation (2013). Creating opportunities for youth in hospitality. Retrieved from http://www.iyfnet.org/sites/default/files/Creating-Opportunities-forYouth-in-Hospitality.pdf 
Jenkins, A. (2018). Ageism and age discrimination in hospitality employment: Issues, challenges and remedies. In R.J. Burke \& J. Christensen Hughes (Eds.), Handbook of Human Resource Management in the Tourism and Hospitality Industries (pp. 216-234). Cheltenham, UK: Edward Elgar Publishing.

Jennings, J., Breitkreuz, R. \& James, A. (2013). When family members are also business owners: Is entrepreneurship good for families? Family Relations, 62, 472-489.

Joliffe, L. \& Farnsworth, R. (2003). Seasonality in tourism employment: Human resource challenges. International Journal of Contemporary Hospitality Management, 15(6), 312316.

Kalargyrou, V.\& Volis, A.A. (2014). Disability inclusion initiatives in the hospitality industry: An exploratory study of industry leaders. Journal of Human Resources in Hospitality \& Tourism, 13(4), 430-454.

Kensbock, S., Jennings, G., Bailey, J. \& Patiar, A. (2016). Performing: Hotel room attendants' employment experiences. Annals of Tourism Research, 56, 112-127.

Kikvidze, Z. \& Callaway, R. (2009). Ecological facilitation may drive major evolutionary transitions. Bioscience, 59, 399-404.

Knox, A. (2016). Coffee nation: An analysis of jobs in Australia's café industry. Asia Pacific Journal of Human Resources, 54(3), 369-387.

Komdeur J. (2006). Variation in individual investment strategies among social animals. Ethology 112: 729-747.

Kusluvan, S., Kusluvan, Z., Ilhan, I. \& Buyruk, L. (2010). The human dimension: A review of human resources management issues in the tourism and hospitality industry. Cornell Hospitality Quarterly, 51(2), 171-214.

Ladkin, A. (2011). Exploring tourism labor. Annals of Tourism Research, 38(3), 1135-1155.

Langer, B. (2005). Consuming anomie: Children and global commercial culture. Childhood, 12(2), 259-271.

Laws, E. \& Scott, N. (2015). Tourism research: Building from other disciplines. Tourism Recreation Research, 40(1), 48-58.

Leiper, N. (1979). The framework of tourism. Annals of Tourism Research, 6 (1), 390- 407. 
Lu, T. \& Adler, H. (2008). Career goals and expectations of hospitality and tourism students in China. Journal of Teaching in Travel \& Tourism, 9, 63-80.

Lub, X., Bijvank, M., Bal, M., Blomme, R. \& Schalk, R. (2012). Different or alike? Exploring the psychological contract and commitment of different generations of hospitality workers. International Journal of Contemporary Hospitality Management, 24(4), 553-573.

Lucas, R. \& Keegan, S.N. (2007). Young workers and the National Minimum Wage. Equal Opportunities International, 26(6), pp.573-589.

Lusch, R. \& Vargo, S. (2014). Service-Dominant Logic: Premises, Perspectives, Possibilities. Cambridge: University Press, Cambridge.

Magd, H. (2003). Management attitudes and perceptions of older employees in hospitality management. International Journal of Contemporary Hospitality Management, 15(7), 393-401.

Martin, E. \& Gardiner, K. (2007). Exploring the UK hospitality industry and age discrimination. International Journal of Contemporary Hospitality Management, 19(4), 309-318.

Martin W., Garg S. \& Zimorski, V. (2015). Endosymbiotic theories for eukaryote origin. Philosophical Transactions of the Royal Society B, 370(1678), 20140330.

Maynard Smith, J. \& Szathmáry, E. (1997). The major transitions in evolution. Oxford: Oxford University Press.

McCole, D. (2015). Seasonal Employees. The link between sense of community and retention. Journal of Travel Research, 54(2), 193-205.

McDonald, P., Bailey, J., Price, R. \& Pini, B. (2014). School-aged workers: Industrial citizens in waiting? Journal of Sociology, 50(3), 315-330.

McIntosh, A. \& Harris, C. (2018). Representations of hospitality at The Special Needs Hotel. International Journal of Hospitality Management, 75, 153-159.

Macdonald, C.L. \& Merrill, D. (2009). Intersectionality in the emotional proletariat: a new lens on employment discrimination in service work. In M. Korczynski \& C.L. MacDonald (Eds.), Service Work: Critical Perspectives (pp. 113-133). Abingdon: Taylor and Francis. 
McDowell, L. (2009).Working bodies: Interactive service employment and workplace identities: Chichester, UK Malden, MA: Wiley-Blackwell.

Merinero-Rodríguez, R. \& Pulido-Fernandez, J.I. (2016). Analyzing relationships in tourism. A review. Tourism Management, 54, 122- 135.

Meyer, D. (2007). Pro-poor tourism: From leakages to linkages. A conceptual framework for creating linkages between the accommodation sector and 'poor' neighbouring communities. Current Issues in Tourism, 10(6), 558-583.

Mooney, S. (2016). Wasted youth in the hospitality industry: Older workers' perceptions and misperceptions about younger workers. Hospitality and Society, 6(1), 9-30.

O’Malley, M. (2015). Endosymbiosis and its implications for evolutionary theory. Proceedings of the National Academy of Sciences, 112(33), 10270-10277.

Paez, P. \& Arendt, S.W. (2014). Managers' attitudes towards people with disabilities in the hospitality industry. International Journal of Hospitality \& Tourism Administration, 15(2), 172-190.

Paracer, S. \& Ahmadjian, V. (2000). Symbiosis: An introduction to biological associations. New York: Oxford University Press.

Pavesic, D. \& Brymer, R. (1989). Industry retention/ attrition of hospitality graduates. Journal of Hospitality and Tourism Research, 3(3), 267-275.

Poulston, J. (2008). Metamorphosis in hospitality: A tradition of sexual harassment. International Journal of Hospitality Management, 27(2), 232-240

Poulston, J.M. (2009). Working conditions in hospitality: Employees' views of the dissatisfactory hygiene factors. Journal of Quality Assurance in Hospitality \& Tourism, 10(1), 23-43.

Price, R.A., McDonald, P.K., Bailey, J. \& Pini, B. (2011). A majority experience: Young people's encounters with the labour market young people and work. In R.A. Price, P.K. McDonald, J. Bailey, J. \& B. Pini (Eds.), Young people and work (pp. 1-17). Surrey, GBR: Ashgate Publishing.

Putnam, L.L., Fairhurst, G.T. \& Banghart, S. (2016). Contradictions, dialectics, and paradoxes in organizations: A constitutive approach. The Academy of Management Annals, 10(1), 65-171 
Richards, G. (2015). The new global nomads: Youth travel in a globalising world. Tourism Recreation Research, 40(3), 340-352.

Richardson, S. (2008). Undergraduate tourism and hospitality students attitudes toward a career in the industry: A preliminary investigation. Journal of Teaching in Travel \& Tourism, 8(1), 23-46.

Richardson, S. (2009). Undergraduates' perceptions of tourism and hospitality as a career choice. International Journal of Hospitality Management, 28(3), 382-388.

Richardson, S. \& Butler, G. (2012). Attitudes of Malaysian tourism and hospitality students towards a career in the industry. Asia Pacific Journal of Tourism Research, 17(3), 262276.

Ritzer, G. (1993). The McDonaldization of society. Thousand Oaks, CA: Sage.

Roberts, K. (2007). Youth transitions and generations: A response to Wyn and Woodman. Journal of Youth Studies, 10(2), 263-269.

Robinson, R.N.S. (2008). Revisiting hospitality's marginal worker thesis: A monooccupational perspective. International Journal of Hospitality Management, 27(3), 403413.

Robinson, R.N.S. (2013). Darker still: Present-day slavery in hospitality and tourism services. Hospitality \& Society, 3(2), 93-110.

Robinson, R.N.S. \& Barron, P.E. (2007). Developing a framework for understanding the impact of deskilling and standardisation on the turnover and attrition of chefs. International Journal of Hospitality Management, 26(4), 913-926.

Robinson, R.N.S., Kralj, A., Solnet, D.J., Goh, E. \& Callan, V.J. (2014). Thinking job embeddedness not turnover: towards a better understanding of frontline hotel worker retention. International Journal of Hospitality Management, 36, 101-109.

Robinson, R.N.S., Kralj, A., Solnet, D. \& Baum. T. (2017). Same old, same old: Time for big hospitality workforce research ideas, CAUTHE Conference Proceedings, Otago University, Dunedin, $8^{\text {th }}-12^{\text {th }}$ February.

Robinson, R.N.S., Ritchie, B. W., Kralj, A., Solnet, D. J., Baum, T., \& Ford, R. C. (2014). An Asia-Pacific core-periphery futures paradox: Divergent worker and tourist mobilities. Journal of Travel Research, 53(6), 805-818. 
Rodó-de-Zárate, M. (2017). Who else are they? Conceptualizing intersectionality for childhood and youth research. Children's Geographies, 15(1), 23-35.

Ruddick, S. (2003). The politics of aging: Globalization and the restructuring of youth and childhood. Antipode, 35(2), 334-362.

Ryan, C. (2015). Trends in hospitality management research: a personal reflection. International Journal of Contemporary Hospitality Management, 27(3), 340-361.

Schlosser, E. (2002). Fast food nation: The dark side of the all-American meal. New York, NY: Perennial.

Simpson, R. (2004). Masculinity at work: The experiences of men in female dominated occupations. Work, employment and society, 18(2), 349-368.

Smith, C. (2018). The precarious and the transitional: Labor casualization and youth in postbubble Japan. Children's Geographies, 16(1), 80-91.

Solnet, D., Kralj, A. \& Baum, T. (2015). 360 degrees of pressure: The changing role of the HR professional in the hospitality industry. Journal of Hospitality \& Tourism Research, 39(2), $271-292$.

Solnet, D., Kralj, A. \& Kandampully, J. (2012). Generation Y employees: An examination of work attitude differences. Journal of Applied Management and Entrepreneurship, 17(3), 36.

Solnet, D., Subramony, M., Ford, R., Golubovskaya, M., Kang, H.J. \& Hancer, M. (2019 forthcoming). Leveraging human touch in service interactions: Lessons from hospitality. Journal of Service Management.

Staff, J., Messersmith, E.E. \& Schulenberg, J.E. (2009). Adolescents and the world of work. In R.M. Lerner \& L. Steinberg (Eds.), Handbook of Adolescent Psychology (pp. 270313): John Wiley \& Sons, Inc.

Subramony, M., Solnet, D., Groth, M., Yagil, D., Hartley, N., Beomcheol Kim, P. \& Golubovskaya, M. (2018). Service work in 2050: Toward a work ecosystems perspective. Journal of Service Management, 29(5), 956-974.

Super, D.E. (1980). A life-span, life-space approach to career development. Journal of Vocational Behavior, 16(3), 282-298. 
Thulemark, M., Lundmark, L. \& Heldt-Cassel, S. (2014). Tourism employment and creative in-migrants. Scandinavian Journal of Hospitality and Tourism, 14(4), 403-421.

Thrall, P.H, Hochberg, M.E, Burdon, J.J. \& Bever J.D. (2007). Coevolution of symbiotic mutualists and parasites in a community context. Trends in Ecology and Evolution 22: $120-126$.

Tinson, J., Piacentini, M., Nuttall, P. \& Cocker, H. (2017). Social belonging and the social collective: Understanding how processes shape youth markets. Marketing Theory, 17(2), 201-217.

Tracey, J.B. (2014). A review of human resources management research: The past 10 years and implications for moving forward. International Journal of Contemporary Hospitality Management, 26(5), 679-705.

Tsai, H., Pan, S. \& Lee, J. (2011). Recent research in hospitality financial management. International Journal of Contemporary Hospitality Management, 23(7), 941 - 971. UNWTO (2009). Tourism and employment: an overview by UNWTO. Presented at the $5^{\text {th }}$ UNWTO international conference on tourism statistics. Retrieved from http://statistics.unwto.org/sites/all/files/pdf/yunis_text.pdf

von Bertalanffy, L. (1950). The theory of open systems in physics and biology. Science, 111(2872), 23-29.

von Bertalanffy, L. (1972). The history and status of general systems theory. The Academy of Management Journal, 15(4), 407-426.

Wallace, M., Lings, I., Cameron, R. \& Sheldon, N. (2014). Attracting and retaining staff: The role of branding and industry image. In R. Harris \& T. Short (Eds.), Workforce Development (pp. 19-36). Springer, Singapore.

Walmsley, A. (2015). Youth employment in tourism and hospitality: A critical review. Oxford: Goodfellow Publisher Limited.

Warhurst, C. \& Nickson, D. (2007). Employee experience of aesthetic labour in retail and hospitality. Work, Employment and Society, 21, 103-120.

Webbink, E., Smits, J. \& de Jong, E. (2012). Hidden child labor: Determinants of housework and family business work of children in 16 developing countries. World Development, 40(3), 631-642. 
Whitley, R. (2007). Business systems and organizational capabilities: The institutional structuring of competitive competences. Oxford: Oxford University Press.

Williamson, D. (2017). Too close to servility? Why is hospitality in New Zealand still a 'Cinderella 'industry? Hospitality \& Society, 7(2), 203-209.

Winker, G. \& Degele, N. (2011). Intersectionality as multi-level analysis: Dealing with social inequality. The European Journal of Women's Studies, 18(1), 51-66.

Wirtz, J., Patterson, P.G., Kunz, W.H., Gruber, T., Lu, V.N., Paluch, S. \& Martins, A. (2018). Brave new world: service robots in the frontline. Journal of Service Management, 29(5), 907-931.

Witzany, G. (2005). From biosphere to semiosphere to social lifeworlds. Biology as an understanding social science. TripleC, 1(1), 51-74.

WTTC [World Tourism \& Travel Council] (2013). Gender equality and youth employment:

Travel \& Tourism as a key employer of women and young people. Retrieved from https://www.wttc.org/-

/media/files/reports/policy\%20research/gender equality and youth employment final.p df

Wyn J. \& White, R. (1997). Rethinking youth. SAGE Publications: London.

Zhong, Y.Y.\& Hertzman, J. (2014). Identifying factors that influence hospitality students' willingness to work with older employees. Journal of Hospitality and Tourism Education, 26(1), 21-28. 